\title{
A PESSOA NO SEU ASPECTO ESSENCIAL E FUNCIONAL OU SUJEITO DE DIREITOS?
}

\section{Carla Eugenia Caldas Barros}

Professora do Mestrado em Direito da UFS, leciona a disciplina Direito Constitucional Empresarial E Seminários de Pesquisa, email: carlaeugenia2010@gmail.com

Constança Marcondes Cesar

Professora do Mestrado em Direito da Universidade Federal de Sergipe; membro do Instituto Brasileiro de Filosofia e do Instituto de Filosofia Luso-Brasileira, e-mail: cmarcondescesar@msn.com

\section{Resumo}

Partindo das reflexôes de Ricoeur sobre a noção de pessoa, examinaremos sua contribuição para a complexificação da noção, na filosofia contemporânea e suas implicações nos diferentes campos em que o Direito se manifesta hoje em especial no Direito do Consumidor, Empresarial e Direitos de Personalidade. Examinaremos o percurso do conceito de pessoa e do direito natural e seus desdobramentos no campo do Direito, ao longo da história, bem como o enriquecimento progressivo da compreensão do homem e da consideração de sua vida na comunidade humana, para que ela expresse de modo crescente, a busca do Estado de Direito, a paz e a justiça de modo a superar os conflitos e paradoxos entre os terceiros que caracterizam a sociedade técnica contemporânea em vários ramos do direito.

\section{Palavras-chave}

Pessoa; Direito Fundamental; Direito natural.

\section{Abstract}

Building on Ricoeur's reflections on the notion of person, we will examine its contribution to the complexity of the notion in contemporary philosophy and its implications in the different fields in which the law manifests itself today especially in the Consumer Law, Corporate and Personality Rights. We examine the route of the concept of person and of natural law and its developments in the field of law, throughout history, as well as the progressive enrichment of the understanding of man and the account of his life in 
the human community, so she expresses increasingly, the search for the rule of law, peace and justice in order to overcome the conflicts and paradoxes among third parties that characterize contemporary art society in various branches of law.

\section{Key words}

Person; Fundamental rights; Natural right.

\section{Introdução}

O ponto de partida da reflexão de Ricoeur sobre a especificidade do direito é a meditação sobre "Quem é o sujeito do Direito? "Gostaria de mostrar que a questão jurídico formal " quem é o sujeito de direito/" não se distingue, em última análise, da questáo moral formal", quem é o sujeito digno de estima e respeito?"(..) E a questão moral formal remete, por sua vez a uma questão de natureza antropológica: quais são as características fundamentais que tornam o si (self, Selbst, ipse) capaz de estima e respeito?

Pode-se dizer que na obra de Ricoeur há uma complexificação das noçóes de pessoa e de sujeito, que caracterizou a filosofia moderna. Ao estudar as contribuiçóes à crítica do cogito em Freud, Nietzsche e Marx , e ao refletir acerca da distinção entre o si e o eu, é que o filósofo francês propóe, de forma inovadora, o exame da questáo do mesmo e do outro e seus reflexos nos planos jurídico e moral.

O primado da pessoa é afirmado por Ricoeur em diversos textos. Para Ricoeur, a pessoa é o homem, ser consciente de si, livre, que tem como tarefa tornar-se si mesmo, realizar suas possibilidades de existência. A consciência, segundo o filósofo, náo é um dado, mas uma tarefa, que engaja a vida inteira. Tornar-se consciente de si, ser fiel a si mesmo, reconhecer a si e aos outros, seus parceiros sem grande aventura do existir, é o que cabe a todo homem, enquanto pessoa, ser espiritual. Inscrever no mundo a dimensão do espírito, reconhecer-se e reconhecer o outro como um análogo a si mesmo, implicará, para o indivíduo, o estabelecimento de laços profundos entre a ética e a política, de modo que a ação esteja voltada para a realização da paz e da justiça. Esta última tem como finalidade expressar o justo, entendido como o difícil ponto de equilíbrio entre o legal e o bom.

A correlação supra indicada entre a valorizaçáo do homem como pessoa e a promoção da justiça e da paz, pelo estabelecimento de laços estreitos entre o ético, o político e o econômico são visíveis na obra de Ricoeur. A justiça é expressão do bem, através da lei, temas centrais na reflexão ricoeuriana sobre o Direito.

1 RICOEUR, Paul. O justo 1 A justiça como regra moral e como instituição. São Paulo: Martins Fontes, 2008, p. 21. 
Para estudar a contribuição de Ricoeur, é preciso tomar como ponto de partida de nossa investigação a compreensão que o filósofo tem da consciência: esta não é um dado imediato, mas uma tarefa. O pensamento filosófico, desde sues primórdios, valorizou a autoconsciência ${ }^{2}$, a busca de um saber verdadeiro sobre si mesmo. Conhecer a si mesmo, saber de si, é identificar-se com a alma racional, com o logos; é , também, principalmente a partir da Idade Média, meditar sobre a pessoa, ser espiritual, dotado de consciência e de liberdade. ${ }^{3}$

A via escolhida por nosso filósofo começa pela meditação sobre a noção de identidade, de ipseidade. Opondo o si ao eu, o pensador reflete sobre a noçáo de mesmidade. Identificando-a permanência no tempo, vai chamá-la de identidade-idem. Reconhece também a identidade-ipse, associada à noção de si; póe em cena uma dialética entre ipseidade e mesmidade, e a a dialética do si e do outro distinto de si. ${ }^{4}$

Ricoeur caminha na sua busca, na pergunta Quem, referente ao sujeito, em direção à noção do que seja o sujeito capaz. E, nesta busca, de forma ascendente, ele nos apresenta “ as mediações de ordem interpessoal e institucional que possibilitam a transição do sujeito capaz a um sujeito de pleno direito que se expressa no plano moral, jurídico e político. (..) $\mathrm{Ela}^{5}$ constitui o referente último do respeito moral e do reconhecimento do homem como sujeito de direito. Se é possível atribuir-lhe esta função, isso decorre de seu nexo íntimo com a noção de identidade pessoal ou coletiva." ${ }^{6}$

"O que falta ao sujeito capaz, cujos níveis de constituição acabamos de percorrer, para que ele seja um verdadeiro sujeito de direito? Faltam-lhe as condições de atualização de suas aptidōes. (...) que se costuma situar sob o emblema do diálogo entre "eu" e "tu"....Somente essas relaçóes merecem ser qualificadas de interpessoais. Mas a esse face-a-face falta a relaçấo com o terceiro que parece tão primitiva como o tu. Esse ponto é da maior importância, se quisermos entender a passagem da noção do homem capaz para o de sujeito real de direito."

2 "Distinguindo, com Heidegger, entre a consciência moral (Gewissen) e a consciência fenomenal (Bewusstein), e ligando a primeira forma de consciência à atestação e ao Selbstheit, e a segunda forma ao Dasein, " modo de ser que somos a cada vez" ,Ricoeur assinala a noçáo de cuidado( Sorge) como o elemento de ligação entre a primeira e a segunda forma de auto-consciência e como fundamento de nosso ser no mundo. $\mathrm{O}$ cuidado adquire, assim, uma dimensão de categoria ontológica, descritiva de nossa condiçáo" . CESAR, Constança Marcondes . O mesmo e o outro : uma perspectiva sobre a noção de pessoa em Paul Ricoeur, , Agora. Papeles Filosóficos, vol.25, n.2, Universidade de Santiago de Compostela, 2008, p.197-206.

3 CESAR, Constança Marcondes. O mesmo e o outro : uma perspectiva sobre a noção de pessoa em Paul Ricoeur, Ágora. Papeles Filosóficos, vol.25, n.2, Universidade de Santiago de Compostela, 2008, p.197-206

4 Ibem idem.

5 capacidade.

6 RICOEUR, Paul. O justo 1 A justiça como regra moral e como instituiçáo. São Paulo: Martins Fontes, 2008, p. 21.

7 Idem. P. 25. 
É neste momento da construçấo do pensamento de Paul Ricoeur que ele remonta aos conceitos de capacidade e efetivação, fazendo da linguagem o suporte da relação interpessoal do diálogo. Ao se debruçar sobre a linguagem, sobre a ética, sobre a ação c Paul Ricoeur chega à concepção de identidade narrativa relacionada com a identidade pessoal. Ressalta o filósofo que um dos lados da compreensão da alteridade é o do confronto entre sujeitos, que passa a existir quando o eu e o terceiro (o outro) interagem.

Ainda no pensamento do filósofo, no texto "Ética e Política", as interseçóes entre ética, política e economia são consideradas, para expressar a originalidade dessa relação, no mundo contemporâneo. Abordando inicialmente o político nas suas relaçóes com o econômico e o social, o filósofo prossegue seu exame considerando o político em relação ao Estado e, finalmente, as características da intersecção entre a Ética e a Política, com a finalidade de entender a luta do homem contra a natureza, mediante a racionalização do trabalho e do consumo. Recorre também a Aristóteles, para descrever o econômico como deveria ser: um espaço de cooperação, para tornar a vida melhor; e a Hegel, para descrever a vida econômica como um "Estado externo" que controla a vida nas comunidades históricas. A distinção entre sociedade e comunidade, será essencial para o exame de Ricouer dos laços entre o econômico e o político. A sociedade diz respeito à vida segundo as regras ditadas pelo Estado; a comunidade implica comunhão e adesão voluntária a regras que expressam a vida de um grupo e sua história, sua cultura, suas tradiçóes. A técnica, expressando a vida econômica, disciplina o sujeito individual levando-o a perceber que não pertence apenas ao grupo restrito de sua comunidade, mas, antes, se insere na vida humana universal.

Criticando a estruturação da sociedade contemporânea, que se caracteriza pela prioridade da economia e da técnica em relação aos valores propriamente humanos, Ricoeur mostra que o político tornou-se mera variante do econômico, refletindo a alienação em que vivemos. Dessa redução do político ao econômico, surgem conflitos agudos entre o ético e o político, agravado por uma profunda insatisfação dos indivíduos que compóem tais sociedades. A razão de insatisfação consiste no fato de, sendo definida apenas em termos econômicos, a sociedade torna-se marcada pelo confronto de grupos rivais, pelo isolamento dos indivíduos e pelo trabalho que expóe uma racionalidade caracterizada, ao mesmo tempo, por ser perfeitamente técnica e "humanamente insensata"; pela "apologia do calculo eficaz", que produz "o estranho paradoxo na qual as sociedades avançadas de hoje estão encerradas (...) competição tecnológica” acirrada e, concomitantemente, dissolução "do núcleo ético-político dessas sociedades" .

Contra essa destruição do humano, na sociedade contemporânea, Ricouer aponta o remédio: a intersecção entre a ética e a política, que pode restituir "ao político sua dignidade própria", fazendo valer a sua "exigência da autonomia face à economia e à técnica", graças a uma ação racional, "inseparável (...) da moral viva, da intenção ética”. 
A comunidade organizada como Estado articula diversas atividades e instituiçóes, de modo que, através do Estado, ela possa se exprimir mediante açóes racionais e práticas coletivas. A cidadania é estudada no campo da filosofia política quando esta trata da açáo racional do indivíduo, enquanto pertencente a uma comunidade histórica. O que define o Estado é sua finalidade, que é a de auxiliar uma comunidade a "fazer sua história", sobreviver, ter existência durável. Nos Estados totalitários, o poder e expressa como força; no Estado de Direito, como poder racionalmente constituído, que assegure a igualdade perante a lei, "a educação de todos para a liberdade, pela discussão", o debate, sobre a forma de ser conduzida a vida em comum.

O Estado-educador é o que assegura "a síntese entre o racional e o histórico, entre a eficácia e o justo". Apresenta-se como uma ideia-reguladora, no sentido kantiano: uma ideia que, como valor-horizonte a ser buscado, inspira a ação: aquela que expressa a liberdade, consolidada através do livre debate, nas escolas, universidades, mídias, vida cultural .

No plano da vida política, na sua relação com o Estado, no mundo contemporâneo, na opinião de Ricouer, só uma fundamentação ética forte pode assegurar a sobrevivência da humanidade, sua liberdade e sua convivência apoiada na justiça e nas leis. A dimensão ética consiste, no âmbito da vida política, na busca do Estado de Direito, na criação de espaços de liberdade, de igualdade perante a lei, e da não violência.

Diz Ricouer: "O Estado de direito (...) é a efetivação de intenção ética na esfera do político".

O estado de Direito é a realização, no plano dos governos, de virtude da prudência; é o ponto axial da noção de democracia, tal como Ricoeur a entende.

A liberdade se realiza através da discussão, do debate, que permite a formação da opinião pública reta, assegurando a participação dos cidadãos na condução de seus destinos.

A democracia assim concebida diminui o espaço entre o povo e o governo, possibilitando o acesso, para um número crescente de cidadãos, à participação nas decisóes que concernem à comunidade a que pertencem.

Quando maior for o consenso assim obtido, mais sólido e mais racional será o Estado. Nele, uma moral de convicçóes e na moral de responsabilidade devem se interseccionar, sem se confundir. Não se trata de socializar o político, nem reduzir o político ao ético, nas sociedades pluralistas do mundo atual. Trata-se de exercitar a tolerância, de considerar a possibilidade de se estabelecer, mediante respeito e justiça, laços com o outro, com o diverso de nós.

Que significa a oposição entre legal e bom, que aparece no título da conferência no Instituto Superior de Estudos Judiciários em Paris, em 1991, e publicada e, no mesmo 
ano, e como se conecta com a mediação de Ricoeur sobre o justo ou a justiça? Significa uma dialética entre o legal e o bom, inerente à ideia justiça entendida no sentido kantiano, como ideia reguladora, valor-horizonte que se reflete na prática social.

Sob o impacto da filosofia kantiana, a perspectiva deontológica a respeito da justiça se tornou dominante. O justo é pensado como conformidade à lei, ao dever, à legalidade. É estabelecida, assim, uma identificação entre justiça e igualdade, uma proporcionalidade: a justiça está para as instituiçôes como a amizade, a solicitude estão para as relaçôes interpessoais.

A noção de homem como pessoa e que se relaciona com terceiros se espelha na consciência coletiva, e se exprime em leis emanadas pelo Congresso Nacional e por outros meios jurídicos, como procedimentos de mudança em seara constitucional, como normas de revisão e bem como princípios e procedimentos institucionalizados no seio da sociedade civil. Aparece no direito civil, no direito empresarial, no direito penal, no direito tributário, propriedade intelectual, direitos da personalidade e outros. Fato que não vem ocasionar nenhuma desagregação à ordem jurídica ${ }^{8}$, por surgimento de novos ramos do Direito. É o homem em relação consigo mesmo, no tempo e no espaço, o homem em relação com $o$ tu, com quem vai se comunicar através da linguagem, que faz surgir relaçôes jurídicas. E, em nada, viria a prejudicar a unicidade do direito que é mantida, agora, sobre vários olhares e saberes.

\section{Direito Natural e Direito Positivo}

O Direito para os Antigos estava subordinado à vontade dos deuses. Dessa forma as leis sempre se colocaram como justas, visto que, não seria possível serem os deuses responsáveis por injustiça. Assim tanto na Grécia como em Roma, ou para os egípcios e o povo israelita, sempre se cumpria o Direito como vontade de suas perspectivas divindades. E, alguns casos, mediante a identificação de seus soberanos com a divindade, e outros como sacerdote que percebiam a palavra divina enfim, tornava-se impossível o questionamento das leis ou do Direito.

$\mathrm{Na}$ Grécia, esta visão místico-religiosa passa a ser examinada, criticada principalmente pelo desenvolvimento forma democrática de governo notadamente em Atenas,

8 A ordem jurídica assim entendida, como a regra social obrigatória que a sociedade edita por seus órgãos institucionalizados no poder, constitui o Direito Objetivo/positivo. Este como reflexo da sociedade subjacente, e, também, fator condicionante dessa realidade, afigura-se uma resposta social á conduta anômica cuja exacerbação ou mesmo a eclosão, por sua interveniência, serão evitáveis. Pontes de Miranda afirma em seu Tratado de Direito Privado, Tomo I, p. 8/9 afirma ter sido a regra jurídica, a criação mais eficiente do homem para submeter o mundo social. É no momento em que os comportamentos já não se ajustam aos controles informais que entra em jogo a norma jurídica e dentro da ordem jurídica, existem regras que objetivam a conformaçáo de comportamentos de indivíduos ou grupos a outras regras de Direito que demonstram baixo poder de persuasão ou até mesmo, por ser frágil na sua eficácia, seja fácil de manipulação. A ordem jurídica se estabelece nas metas culturais, como valores, como também como meios socialmente admitidos para se chegar a tais metas citadas. 
quando as leis passam a ser fruto de decisóes humanas, de homens reunidos em Assembleias. Nesta época frutificaram diversas interpretaçóes acerca do Direito, destacando-se a afirmação dos sofistas sobre serem as leis derivadas da vontade da maioria, um obstáculo à vontade dos mais fortes. Os gregos pensavam que tanto a natureza física como a social regia-se por leis simples, eternas, universais. Os sofistas ${ }^{9}$ vão fundar as leis no debate, na discussão, característicos da democracia. Podemos afirmar que os sofistas têm muito em comum com os defensores do direito natural, no período do iluminismo. ${ }^{10}$

Numa perspectiva diferente, Platão percebia ou identificava nas leis à virtude das instituiçóes, à sabedoria, que inspirava a organização da sociedade, de tal forma que se mantivessem o equilíbrio e a paz social. Em termos de organização estatal para a elaboração e administração das leis desejava um governo de sábios, autocráticos, na ausência ou na impossibilidade eventual de se ter um soberano sábio. Segundo Platão o Estado é o grande educador do homem. Dessa forma, o Direito como expressão do conhecimento dos sábios seria sempre carregado de justiça, pois a virtude (o bem) era o fundamento das leis.

Aristóteles ${ }^{11}$ avançava um pouco mais em relação à ideia platônica de Direito e de justiça, já por conhecer as ideias de final de vida do mestre, após a fracassada experiência deste na Magna Grécia, mais para ver nas leis um conteúdo ético, de justiça, como fim a ser buscado pelos soberanos. Aristóteles afirmava que a lei natural se realiza através do Direito positivo, que aplicava a justiça conforme as circunstâncias do momento ou época histórica. Assim dever-se-ia ajustar a lei existente à solução ideal. Diz Bodenheimer: Aristóteles "Concebeu uma forma de Estado baseado no Direito como sendo o único modo prático de conseguir uma existência satisfatória, para ele o principal objetivo da organização política”. ${ }^{12}$

Esta face metafísica de evolução do Direito Natural construiu-se em extraordinário avanço em relação ao período místico religioso que apontamos e veio a traçar poderosas diretrizes teóricas para construção de todo o pensamento ocidental até os nossos dias.

9 “os sofistas valorizaram primordialmente as relaçóes interpessoais, imprescindíveis para a existência do Direito, ajudaram a profundar discussōes políticas, debates morais, escritos históricos e filosóficos, o importante e polêmico debate promovido acerca dos conceitos de nomos e physis, a convenção e a natureza” DE AVILA, Flávia. Direito e Direitos Humanos: abordagem histórica-filosófica e conceitual, Curitiba: Editora Appris, 2014, p.23.

10 “Du Droit naturel sofistique lorsqu'il oppose le droi positif em viguer au Droit Naturel, est d'établir non selement la perfectibilité accidentelle, mas l'injustice des lois. Les lois ne représentent pas, aux yeux des sophistes, uma valeur sacré de la Polis, fruit de la tradition et garantie de as conservation; eles sont des instruments artificiels servant les intérêts des puissnts."ROMMEN, Henri. Le Droit Naturel Histoire et Doctrine, Paris: Egloff, 1945,p.23.

11 Considerado por alguns, o pai do direito natural pois a sua teoria do conhecimento e da metafísica subsidiaram à ética e por conseguinte ao direito natural, um fundamento sólido.

12 BODENHEIMER, Edgar. Ciência do Direito. pg. 24 in Políticos. 
Com a decadência do Império Romano e o ulterior surgimento do Cristianismo verificamos o soterramento da cultura grega, colocada como visão pagã do mundo, e assistimos ao desenvolvimento de ideias que procuravam definir o mundo segundo a vontade de um só Deus, que tudo determinava, segundo a interpretação da Igreja. ${ }^{13}$ Neste sentido, ciência e religião eram uma só coisa, um só objeto. O Direito surge nesta mesma visão, não mais como uma vontade direta da divindade, mas como vontade humana submetida à divindade. Como vontade humana, falível, razão porque dever-se-ia sempre buscar nas palavras de Deus, apresentadas pela Igreja, a inspiração na produção das leis. Tanto mais Leis seriam justas, tanto mais se aproximassem da doutrina cristá. Como expoente deste pensamento, podemos citar São Tomás de Aquino ${ }^{14}$, fundador da escolástica, que fundamentava o racional com o produto direto da força divina, vinculado à noção de que a inteligência venha a ser dom de Deus aos seus filhos diletos. O Direito Natural é apenas um reflexo incompleto e imperfeito dos ditames da razão divina, porém ele habilita o homem a conhecer ao menos alguns dos princípios da lex aeterna, dizia Santo Tómas de Aquino na Summa Theologica, onde todos os atos virtuosos são prescritos pela lei natural.

Esse pensamento dominante em toda a Idade Média e que nada mais era que o fruto das alianças entre a Igreja Católica e os diversos soberanos em que aquela detinha o monopólio da ciência, da cultura e da religião, as quais coexistiam submetidas a um Direito Canônico, ao lado do poder dos Estados que geriam os elementos da vida material dos homens, sem prejuízos das influencias do D. Canônico, no Direito Comum. Nessa fase inicia-se o desenvolvimento de um Direito Internacional incipiente tendo em vista de um lado os conflitos sempre existentes e de outro o poder dos Papas que proporcionaram incerto equilíbrio de forças.

Outra grande contribuição doutrinária da escolástica da época renascentista é o direito das pessoas ${ }^{15}$ que é o direito das pessoas que convivem em comunidade, sendo o direito positivo das mesmas.

13 "Les Pères de l'église ancienne utilisèrent le Droit Naturel stoicien, dans les axiomes duquel ils trouvaint des príncipes d'argumentation pour annoncer la Doctrine chrétienne d'um Dieu personel, Créateur, auteur de la loi étenelle e t de la loi morale naturelle, promulguée par la voix de la conscience et de la raison." Rommen, Henri, op. Cit. P.56.

14 "De la dépendance intime de toute loi positive par rapport â la loi naturelle Saint Thomas déduit avec raison que le droi postif ne peut pas contredire le Droit Naturel: dans l'exacte mesure où il le contredirait il ne seriat em aucune façon une loi et ne pourrait pas obliger en conscience; car c'est précisement dans l'obligation de conscience que reside la force et la signification de la loi." ROMMEN, Henri, p.76/77.

15 "La norme fondamentale de ce Droit des gens positif, outre les príncipes du Droit naturel est immédiatement le príncipe:Pacta sunt servanda. Les Droit positif des peuples concerne la Doctrine de la guerre, de l'armistrice, de la paix, des échamges internationaux, des contrats de commerce et enfim le droi diplomatique." Ibem idem p. 91/92. 
É a época de Hugo Grotius ${ }^{16}$ e o ápice da doutrina de forma sintética "pacta sunt servanda" no direito natural e com o direito positivo, a qual já vinha se delineando anteriormente pela escolástica. É a passagem do direito natural metafísico para o direito natural racional. Grotius define o Direito Natural como "um ditame da reta razão, que nos mostra que um ato, conforme esteja ou não em conformidade com a razáo natural, contém em si mesmo uma qualidade de baixeza ou de necessidade moral". ${ }^{17}$ Para Grotius, duas são as fontes por ele consideradas como base para se conhecer a ordem humana: a sociabilidade e a razão.

Porém, o mais importante para evolução do pensamento jurídico, apesar da Idade Média de ter sido chamada da Idade das Trevas, foi ter surgido a possibilidade aberta de uma crítica do Estado e do Direito em razão de uma preocupação provocada quanto à origem e justificaçáo do poder público. Ora, numa época em que embora unidos por alianças políticas, Igreja e Estado desenvolvem-se separadamente com ideologias próprias, buscam os pensadores a justificação das leis, que não são monopólio da intelectualidade eclesiástica, que as asseguravam através da interpretação do discurso da palavra divina no sentido de sempre procurar adequá-la, quando não fosse evidente o laço entre o texto sagrado e a situação concreta.

Para o enfraquecimento do poder político da Igreja, que em alguns Estados já tornava possível o questionamento da visão católica do mundo, foram surgindo pensadores que procuravam examinar as condiçóes do desenvolvimento social e político dos povos, como por exemplo a Reforma proposta por Lutero e Calvino, que abriu espaço para a dissociação do pensamento científico em relação ao pensamento religioso principalmente com uma nova hermenêutica/ interpretaçâo dos textos cristáos.

Por outro lado o desenvolvimento do absolutismo a partir das disputas pelo poder político nos diversos Estados proporcionava o surgimento de um pensamento mais racional ou realista da elaboração do Direito e da justificação do estado.

Aberto estava o caminho para o Renascimento onde se buscou a inspiraçấo dos clássicos gregos para revitalizaçáo do pensamento ocidental já saturado do dogmatismo hermético e já então estéril das ideias prevalecente pelo longo período da Idade Média. Preparava-se então, o pensamento que iria ganhar força na sustentação da revolução teórica e prática realizada por uma burguesia citadina ascendente. É a época de Maquiavel, Erasmus, Beccaria, e principalmente Hobbes, Locke, Rousseau, Montesquieu. A concepção

16 "Le mérite impérissable de Grotius est d’avoir systematisé le Droit des gens et de lui avoir donné une solide base naturelle. (...) Mais, Il ne sait plus distinguer nettement, comme l'avait fait Suarez, entre le contenu Naturel est le contenu positif du Droit des gens, ce qui amènera Pufendorf à identifier le Droit Naturel te le Droit des gens.! Ibem idem, p.98.o

17 De jure Belli ae Pacis - Clássicos de Direito Internacional; 
do Direito natural vincula-se a uma ideia abstrata e imaginária da natureza humana. Já vimos que na Antiguidade justificava-se o Direito por ser ele nada mais, nada menos do que a expressão direta da vontade divina. As leis eram leis divinas.

O Renascimento veio proporcionar uma efetiva volta à natureza com preocupação central da filosofia ocidental. Se é verdade que tanto na Antiguidade como nos séculos que se seguiram a ideia da natureza fora estabelecida diretamente por Deus, ou pelos homens no desenvolvimento da sua inteligência, é na retomada do pensamento grego pelos renascentistas, influência esta que se espalhou por todas as manifestações culturais (artes, pintura, teatro, música), que a ideia da existência de um Direito natural ganhou contornos teóricos definidos.

Na modernidade, Hobbes preocupado com a justificação do Estado vai estabelecer o seu princípio: o homem o lobo do homem, o Estado só pode se fundamentar na necessidade de disciplinar da vida em sociedade a evitar que os homens se destruam entre si. Via ele que a grande questão humana vinha a ser a conciliação de duas necessidades básicas - a segurança e a liberdade. Todos os homens ao nascerem livres e egoístas pretendem no exercício de sua liberdade, submeter os outros a sua vontade. Por ser de todo impossível a coexistência das diversas vontades individuais livres no mesmo espaço social, é necessário que cada qual abra mão de uma parte substancial dessas vontades livres para transferi-las a um soberano - ou Estado que exercerá a força recebida de cada um de seus súditos para coibir em todos, o excessivo egoísmo desestabilizador da ordem social. O Estado (Leviatã) forte é a opção necessária de todos pela segurança. Em consequência Hobbes estabelecia que as leis ditadas pelo soberano não poderiam nunca serem desobedecidas, já que justificadas pela opção da entrega da liberdade. Apenas em casos extremos em que os soberanos claramente estivessem utilizando a força decorrente da cessão das diversas liberdades individuais, não em proveito de todos, mas apenas para si mesmo.

Montesquieu escreve o Espírito das leis, e formula sua clássica divisão de poderes de forma a resguardar os cidadãos da mão forte dos governos. França, Inglaterra e, mais tarde, os Estados Unidos, formularam suas constituiçóes liberais que preservam os valores fundamentais do homem, sempre estabelecendo a liberdade como o direto natural de todos.

Rousseau parte da ideia de que a origem e a fundamentação do Estado e do Direito devem ser verificados na própria natureza dos homens reunidos em sociedade, entretanto via ele o homem naturalmente bom, sendo a sociedade, o seu elemento corruptor, daí porque a necessidade de que se estabelecesse um Contrato Social que proporcionasse aos homens colocados individualmente manterem-se o mais próximo possível do seu estado natural. Liberdade, e não repressão é o objetivo do Estado. As leis que deveriam ter sempre em vista a manutenção da maior liberdade possível de todos os indivíduos. Esta 
última ideia vem a ser desenvolvida por Locke que já procurou traçar os contornos do exercício do poder. Para Rousseau, a vontade geral é a ideia central da sua filosofia; a lei deve ter um caráter de generalidade e ser igualmente aplicável a todos, nos limites das suas determinaçóes.

Estas ideias eram, sob medida, para a fundamentação do movimento burguês que a partir do desenvolvimento do comércio e da pequena indústria vinham progressivamente acumulando poder político com vistas à transformação de toda a civilização ocidental no que seria chamado de Revolução Liberal.

O Direito tem por base, finalmente, a racionalidade humana, social, com a participação plena de cada indivíduo em sua formação. É o tempo da Revolução Francesa, do forte conteúdo valorativo - liberdade, igualdade e fraternidade - não porque transmitido por deuses ou filósofos, mas porque próprio da própria existência da sociedade. $\mathrm{O}$ homem é um animal político, ser social. E a razão humana haveria que construir o Estado e as leis que pudessem manter os indivíduos em paz e livres. É a época dos enciclopedistas, dos pensadores que procuravam a configuração de um Estado que nunca permitisse a volta ao passado da repressão das liberdades, notadamente do livre pensar. No campo econômico, o Estado não poderia interferir no livre-comércio, não deveria possuir riquezas, mas apenas o necessário para manter os serviços públicos.

No fim da modernidade, Adam Smith, cujo A Riqueza das Naçôes, mostra que a mão invisível dos mercados, através da oferta e da procura, propiciaria a prosperidade geral. E Ricardo defende o livre comércio, livre-cambismo de modo que, cada povo produzisse o que lhe fosse s fácil, e trocassem entre si, sem barreiras alfandegárias, gerasse prosperidade internacional. É a separação da Igreja do Estado, tempo da liberdade de crença. Época em que se devia fugir das coletizaçóes, como os sindicatos, que lembravam as corporaçóes de ofícios, já que cada qual deveria ter a liberdade de trabalhar como lhe aprouvesse. Enfim, a razão humana apontava sempre em direção à liberdade individual como o fim de toda a vida em sociedade, sempre fundada na natureza.

\section{A Reação Positivista}

A Revolução Industrial, que efetivamente mudou a face do mundo no século XIX, trazia em seu bojo toda uma séria de consequências desastrosas que fariam tender o pêndulo da história humana para o lado da visão hobbesiana. A igualdade jurídica é sufocada pela desigualdade econômica. Ora, como ser livre, vendo seus filhos trabalharem em ruinas de carvão de 14 a 16 horas por dia? Como ser livre sem comida, descanso e lazer? Para que liberdade e igualdade se faltam as condiçóes mínimas de sobrevivência? E, mais, que liberdade, que igualdade, se uns vivem bem, e outros mal sobrevivem? Liberdade de estar preso às fabricas? Começa a reação à situação desumana. 
A questão social avoluma-se, trazendo seguidas revoltas populares. Ideias que apontavam na direção da verdadeira igualdade, da verdadeira liberdade, desenvolviam-se cada vez mais. Eram os socialistas, utópicos, cristãos, solidaristas, etc. que mostravam a condição humana e pensavam o mundo da liberdade e igualdade como sendo o da repartição da riqueza entre todos. Na Alemanha, o pensamento de Kant o luminar da filosofia ocidental, no século XVIII e que não chegou a viver diretamente a revolução liberal, a função do Estado é garantir o cumprimento da lei fundada na razão e na valorização da pessoa humana. Hegel, no século XIX, herdeiro e crítico da tradição kantiana afirmava necessidade de um Estado forte que representasse o Espírito Nacional, a Vontade Absoluta. Na vertente esquerdizante dos herdeiros de Hegel nasce o marxismo, chamado de socialismo científico, pretendendo abolir a propriedade privada, exterminar os burgueses, erigir a ditadura do proletariado.

Nesse mundo de crises sociais, que caracterizaram a segunda metade do século XIX, decorrentes da miséria produzida pelo capitalismo selvagem, de desajustes econômicos internacionais que iriam mais tarde preparar as guerras do século XX, fomentavam-se as ideias que iriam, de um lado, questionar a própria existência de direitos naturais e, de outro, estabelecer os direitos sociais (ou coletivos) que provocariam um avanço cada vez maior do Estado em relação aos indivíduos, até chegar à sua confirmação moderna - o fascismo, o nazismo, o comunismo.

E, é na esteira das crises sociais que vai perdendo o Direito Natural a importância que conseguiu conquistar. Montesquieu, Rousseau, Locke, e Kant dão lugar a Hobbes, Hegel e Marx. O contrato social perde sentido frente ao Leviatá, a igualdade formal cede à igualdade proletária, a divisão de poderes é substituída pela unidade do Poder Absoluto, do Espírito Nacional, a lógica clássica é questionada pela lógica dialética.

Era necessário fazer algo para salvar o ideário da revolução burguesa, os valores da civilização ocidental, da natureza humana, estavam em perigo. A solução foi o recuo: na economia, o intervencionismo; na filosofia, o positivismo.

No Direito, o positivismo pretendeu como por ciência jurídica dos valores e fatos sociais, ao recusar também a metafísica e o Direito Natural ${ }^{18}$. Como resposta, tanto ao jusnaturalismo, quanto ao sociologismo, e tendo em Kelsen seu maior jus filósofo, passa a explicar o Direito através da sua própria formulação, (norma hipotética fundamental). O Direito se esgota em si mesmo. Com isso, salva-se a ciência jurídica do entrechoque de ideias políticas que o mundo ainda em crise intelectual ainda não superou. "Sob o enfo-

18 "Cabe ter em conta náo só que, pelo menos, dois dos mais significativos representantes do positivismo jurídico - Hobbes e Hart - admitem a existência de um Direito Natural, como também que outros elementos há que são igualmente definidores e individualizadores do positivismo jurídico.”TEIXEIRA, Antonio Braz.Sentido e valor de Direito. Introdução á filosofia jurídica, Lisboa: Imprensa nacional- Casa da Moeda, 2006, p.55. 
que kelsiano, a norma jurídica tem como objeto regulamentar a conduta dos indivíduos, tendo, pois, caráter prescritivo, desde que criada pela autoridade competente, revestida do poder de prescrição. Assim sendo, a relação entre norma e comportamento humano é de subordinação"19.

Já Hart, na sua textura aberta, a regra de conhecimento vem, então desempenhar, segundo Braz Teixeira , um papel análogo ao da norma fundamental na teoria pura do direito. (....)enquanto a norma fundamental kelseniana é um pressuposto lógico-transcendental da ordem jurídica, a regra de reconhecimento é um mero dado empírico, cuja existência pode ser comprovada pela experiência." ${ }^{20}$ Hart admitia um Direito Natural de conteúdo mínimo.

Atualmente, o Direito Natural, ao contrário do que pensaram muitos, não está morto. Poderíamos citar diversos dispositivos legais que consagram princípios jurídicos nascidos no interior do jusnaturalismo, por exemplo, o princípio do direito civil/direitos de personalidade e de direito constitucional e dos direitos fundamentais.

Mas o grande papel o jusnaturalismo vem representando parece mesmo ser o de servir de critério de legitimação das leis, procurando buscar nos eternos valores da natureza humana, os referenciais necessários à difícil identificação do Direito com a Justiça. É o caso, por exemplo, atualismo, dos dispositivos expressos na Declaração dos Direitos do Homem que permanece, hoje, como o grande desafio lançado a partir das ideias jusnaturalistas, para a construção de uma sociedade que corresponda aos anseios máximos de todos os homens, os quais transformam o Estado na entidade propiciadora da felicidade humana entendida, não só como coletiva, mas também como individual . Expressa esperança de que as leis, o Direito, nunca mais venham a servir para confirmar que o "lobo seja o lobo do homem", mas, ao contrário, para propiciar que todos vivamos, senáo como "bons selvagens" ao menos como homens verdadeiramente livres, iguais e fraternos..

\section{Pós-Positivismo}

"Este movimento representa um esforço de superação do embate entre o positivismo e o jusnaturalismo, tendo, para este fim, grande relevância a teoria dos princípios. Paulo Bonavides expóe que na fase pós-positivista os princípios passam a ser tratados como direito e que neste período a doutrina do Direito Natural e a do velho positivismo ortodoxo vieram abaixo, sobretudo pelas críticas de Ronald Dworkin. Este reconhece a "possibilidade de que tanto uma constelação de princípios quanto uma regra positivamente estabelecida podem impor obrigação legal." ${ }^{1}$

19 KELSEN, Hans. Teoria geral das normas. Trad. Batista Machado. São Paulo: Martins Fontes, 1985. p. 181-2.

20 TEIXEIRA, Antonio Bras, ibem , p.73.

21 Tristáo, Ivan et al , p.5557. 
A teoria dos princípios se converteu no coração das Constituiçóes, passou a ser considerado o oxigênio das Constituiçôes, na época do pós-positivismo.

Com o neoconstitucionalismo "assiste-se a um período de reaproximação do direito com valores morais, éticos e políticos. Não se pretende com isto, o renascimento do jusnaturalismo mas, seguramente, busca-se a reestruturação ou o equilíbrio do ordenamento positivado com inspiração na razão prática, na teoria da Justiça e na legitimidade democrática. (...) é o que se convencionou chamar virada kantiana do pós positivismo. Sinteticamente a filosofia pós-positivista procura ir além da estrita legalidade para interpretar o sentido do dispositivo normativo através de novos métodos da hermenêutica jurídica e filosófica. Admite a crença em princípios universalmente válidos com força normativa, reintroduz no ordenamento jurídico valores indispensáveis à garantia da dignidade humana, além de construir uma teoria dos direitos fundamentais." 22

Diz Margarida Lacombe que o pós-positivismo, como movimento de reação ao modelo kelseniano de negação a valores, abre-se a duas vertentes. Uma delas, que segue a linha de Dworkin e Alexy, busca recuperar a força normativa dos princípios de direito, com todo seu potencial valorativo. A outra procura, nos fundamentos que sustentam as decisões judiciais, sua força lógico-legitimante, como faz Chaim Perelman, por exemplo, finalizada com a criação da "norma-decisão". ${ }^{23}$

“Todavia, não há dúvida de que, para esses autores, os direitos individuais são universais, devido ao seu enraizamento na natureza humana. Isso significa que a verdade desses direitos reside no dever que eles impóem a cada qual, portanto a todos e para todos. Ou seja, nunca desejar para si o que se recusaria a qualquer outro. Em outras palavras, o direito, em cada sujeito, é inseparável do dever que comanda universalmente o princípio de sociabilidade. (...) Para adquirir a juridicidade de que carece, "o direito provisório" do estado de natureza tem que se tornar, no estado civil, um direito peremptório, segundo Ch. Wolff. (...) Enquanto a legislação positiva do Estado não os tiver avalizado e garantido, os direitos do indivíduo permanecem direitos latentes, uma simples promessa de direito." ${ }^{24}$

"As inúmeras tentativas de definição que pontuam o corpus das obras jurídicas na história do pensamento impõem uma dupla constatação: a multivalência e a maleabilidade do direito. Essas duas características constituem um obstáculo epistemológico para a sua definição. (...) A dificuldade é ainda maior porque o conceito de direito é não só confuso como maleável, não por acidente, mas por natureza” 25

22 JABORANDY, Clara Cardoso Machado. A influência da hermenêutica constitucional para a formação do raciocínio do intérprete in Hermenêutica Aplicada, São Paulo: Saraiva, 2014, p.59.

23 LACOMBE, Margarida apud Ivan Tristão, op. Cit. P.5559.

24 GOYARD - FABRE, Simone, op. Cit. P.33/34.

25 Idem, p. 41. 
O homem, hoje, encontra em várias concepçôes de direito o verdadeiro sentido do sujeitos de direitos. É também o momento em que se depara, segundo Canotilho com "direitos" que se propóem no horizonte da ação humana. O conteúdo está aberto no seio da pretensão da justiça, abrindo espaço aos mandamentos de otimização da pretensão de correção (Robert Alexy), ao seguir a lógica de aprimoramento e expansão dos campos dos direitos reconhecidos e a reconhecer. A norma jurídica não se confunde mais com o texto constitucional. "A norma fattispecie aberta dá ensejo aos direitos fundamentais materiais constitucionais". ${ }^{26}$

A Constituição emite reflexos além do próprio texto constitucional, que segundo, Paul Ricoeur "somente a relaçáo com o terceiro, situado no plano de fundo da relação com o tu confere base à mediação institucional exigida pela constituição de um sujeito real de direito, em outras palavras, de um cidadão." 27

A abertura do sistema jurídico provocada pela amplificação do âmbito dos direitos fundamentais é inevitável, é uma abertura qualificada.

"A disciplina da teoria geral do direito tem objeto, conteúdo e utilidade para fundamentar a análise sobre o fenômeno jurídico da nova hermenêutica e o (neo)constitucionalismo, tendo papel importante na formaçáo do novo jurista, por instruí-lo com conhecimentos suficientes para superar o normativismo dogmático e orientá-lo por um caminho mais adequado. A nova hermenêutica é um dos melhores caminhos a ser trilhado pelos juristas para superaçáo de tal paradigma, pois é amparada por valores legítimos de uma sociedade democrática de direito. Para tanto, apresenta-se a noção de positivismo e seu modelo de superaçáo, o pós-positivismo, onde os princípios passam a ser tratados como direito, viabilizando a introdução de valores no ordenamento jurídico e a resolução dos casos deforma mais justa." 28

Atualmente, a centralidade, a unicidade, a unidade de algo (esse sujeito fora da história, ou fora do diálogo, base da teoria do direito) se dilui diante da visão do sujeito de direitos segundo Paul Ricoeur. Direitos que se propóem no horizonte da ação humana. Tendo aí a manifestação da essência jurídica, norma inicial do fato jurídico expresso no ordenamento jurídico, tem vigência em determinado tempo é ao mesmo tempo norma inicial de fato em determinado tempo e norma final e inicial de novo tempo, que ao mesmo tempo apresenta um novo horizonte , a norma jurídica posta teria a natureza jurídica de norma fattispecie inicial ao mesmo tempo final e assim sucessivamente, de forma

26 CANOTIlHO, J.J. Gomes . Op. cit. P.401.

27 RICOEUR, Paul. O justo 1 , p.25/26.

28 TRISTÃO, Ivan e Zilmar Fachin in Teoria geral do Direito e suas relaçôes com a nova hermenêutica e o (neo) constitucionalismo. Trabalho apresentado no XXII do CONPEDI em 2008. 
adequada. Há uma ruptura com o já estabelecido e a nova ordem (norma jurídica inicial/ final) se refugia no ordenamento jurídico positivo que pode ser justo ou não.

A norma jurídica ${ }^{29}$ se auto alimenta, não só da política, da ética, da economia. Por isto que a norma jurídica sempre estará no plano superior para garantir a ordem e segurança jurídica e ao ser um marco regulatório inicial , ela comporta em sua natureza jurídica, a finitude e a completude do sistema. A norma jurídica marca a mudança com as ideias do passado e do futuro. Adquire segundo Alexy, a fundamentabilidade formal no ordenamento jurídico e a sua fundamentabilidade substancial, quanto ao conteúdo. $\mathrm{O}$ jusnaturalismo pode ter encontrado seu fundamento na atualidade, na teoria dos direitos fundamentais. A preocupação com o direito posto vinda do jusnaturalismo e bem como os anseios do homem podem na teoria dos direitos fundamentais e seus desdobramentos, ter repousado seus anseios.

Será sempre a norma jurídica fundamental ${ }^{30}$ porque e sempre estará vigente no ordenamento jurídico iniciando e finalizando épocas, finitude e completude do sistema ad eternum. Final de um tempo passado e ao mesmo tempo iniciando o futuro.

A cláusula aberta será sempre renovada com o conteúdo da pretensão, tendo princípios como ponto de partida. Daí surge a necessidade do direito, para dar plenitude ao fato social que venha a surgir na humanidade. Quanto á constituição rígida e constituição flexível. A Norma jurídica inicial/ final, finitude e completude em si mesma, faz com que a Constituição rígida aceite também a Constituição flexível.

A ideia de estabilidade e rigidez de Canotilho como também a questão da polaridade dos elementos da estabilidade e flexibilidade como um problema de coordenação justa de Konrad Hesse sustentam que a norma jurídica é inicial e final ao mesmo tempo , pois garante a estabilidade do sistema entre a constituição escrita e aquela que está por vir, a material. A Constituição seria tanto a lei Fundamental do estado como a lei fundamental da sociedade.

A base desta estrutura conduz a certa estabilidade no âmbito dos direitos fundamentais através das duas formas de argumentação Alexyana: argumentação prática geral e

29 "Destaque-se que a norma jurídica é interpretada em três dimensões, harmonicamente articuladas:

a) semântica: investiga as relaçóes paradigmáticas da norma, ou seja, todos os sentidos aproximativos e opositivos que se encontram presentes em sua estrutura de profundidade;

b) sintática: relaciona as normas de um mesmo texto com um contexto, em atividade intelectual, de modo a investigar antinomias jurídicas e o caráter sistêmico das normas das diversas áreas jurídicas, além de seus inter-relacionamentos com outras realidades, normativas ou não;

c) pragmática: verifica a finalidade funcional da norma, sua aplicabilidade real no mundo concreto" PEREIRA, Ademar. In Contribuiçấo da dogmática jurídica para a Ciência do Direito e suas relaçôes. Revista Direito Mackenzie. N. 2 - Ano 1, p. 186.

30 "A norma jurídica é o centro de interesse da Ciência do Direito, pois é a positivação jurídica que cria o Estado e estabelece normas de conduta para assegurar a ordem jurídica”. PEREIRA, Ademar. Op. cit. p. 187. 
argumentação jurídica. "Quanto mais intensiva é uma intervenção em um direito fundamental, tanto mais graves devem pesar os fundamentos que a justificam." 31

E, é quando a norma jurídica ${ }^{32}$ vai expressar sua finitude e completude no sistema, ao representar o passado e o futuro. Será sempre uma norma jurídica inicial e ao mesmo tempo final no sistema jurídico positivo vigente e, como também do futuro.

Direito Civil preocupado com a tutela dos direitos de personalidade e com a promoção da personalidade humana foi esta teoria, o pensamento adotado por José de Oliveira Ascensão quando ele nos afirma que é este o lugar próprio (direito civil) dos direitos de personalidade. Assente o ponto de partida substancial há que desenvolvê-los na sua teoria geral e nas suas manifestaçôes singulares que se revelarem necessárias. Há que ir muito além dos escassos preceitos do Código Civil. Os direitos de personalidade são atributos da pessoa humana e que em certos setores também assim o são considerados. O que vem a diferenciar é o plano em que elas se encontram. $\mathrm{O}$ art. $5^{\circ} \mathrm{da}$ Constituição contempla a maior parte dos direitos de personalidade, mesmo aqueles que não se encontram no $n u$ merus clausus também são considerados como direitos de personalidade, e como direitos fundamentais. Neste caminho vem trilhando a nossa teoria Geral do Direito, para diminuir o abismo entre a filosofia e a ciência do direito, no campo do delineamento do que seja Pessoa e em que campo, e em qual setor do Direito deverá ser inserida.

"Muitos dos direitos fundamentais são direitos de personalidade, mas nem todos os direitos fundamentais são direitos de personalidade. (...) Contudo, hoje em dia, dada a interdependência entre o estatuto positivo e o estatuto negativo do cidadáo, e em face da concepçáo de um direito geral de personalidade como "direito à pessoa devir" cada vez mais os direitos fundamentais tendem a ser direitos de personalidade e vice versa."

Diz ainda o Jurista/professor José de Oliveira Ascensão.

"Que a formalização da Pessoa vai tão longe que alcança os próprios direitos de personalidade, (...) os direitos de personalidade deixam de ter aquele mínimo que se impóe em toda a sociedade para se transformarem numa categoria oportunística, muito frequentemente destinada a tutelar interesses patrimoniais sob a capa de uma promíscua proteção da personalidade." ${ }^{33}$

E, mais do que nunca, a teoria dos direitos fundamentais acompanha o pensamento do Prof. José de Oliveira Ascensão ao afirmar que a base desta estrutura (apresentação

31 ALEXY, Robert. Constitucionalismo Discursivo. Porto Alegre: Livraria do Advogado, 2015, p.68.

32 A norma jurídica é o centro de interesse da Ciência do Direito, pois é a positivaçâo jurídica que cria o Estado e estabelece normas de conduta para assegurar a ordem jurídica. PEREIRA, Ademar. Op. cit. p. 189.

33 ASCENÇÃO, José de Oliveira O Direito Civil como o Direito Comum do Homem Comum in www. idb-fdul.com, p. 52. 
atual dos direitos fundamentais e o neoconstitucionalismo) conduz a certa estabilidade no âmbito dos direitos fundamentais através das duas formas de argumentação Alexyana: argumentação prática geral e argumentação jurídica. "Quanto mais intensiva é uma intervenção em um direito fundamental, tanto mais graves devem pesar os fundamentos que a justificam."

Logo a proteção dos direitos de personalidade pode ter a segurança jurídica apesar da atipicidade generalizada dos mesmos. E, diz correto o nosso professor que os artigos 11 a 21 do Código Civil fazem apenas referencias a alguns tipos, que não são sequer os de maior importância. A teoria dos direitos fundamentais vem consagrar a própria Pessoa Humana, ao admitir que outros direitos não exemplificados em lei possam ser considerados como tal, não deixa de ser um breve retorno ao direito natural como sempre uma constante histórica. A pessoa humana voltaria a ser a base da teoria geral do direito Civil. Com diz Alexy apud Clara Jaborandy "em casos de conflito entre regras e princípios, a solução deverá ser fundamentada no sopesamento entre o princípio adstrito e o outro princípio colidente." 34

Como diz ${ }^{35}$ Prof. Ascensão , "os direitos de personalidade (...) há que ir muito além dos escassos preceitos do Código Civil. O jurista não é um refletor de leis, é um revelador do Direito. Neste domínio tem um largo campo aberto á sua indagação, porque como dissemos há que determinar o que é essencialmente exigido pela Pessoa independentemente de estar ou não previsto por lei."

Dentre os direitos de personalidade ligados á propriedade intelectual, temos os direitos de personalidade de base ética. Encontramos neste rol, os direitos de personalidade do autor que une a criação da obra e sua inserção em um corpo mecânico. "Na integraçáo desses direitos é que se acha a unidade da categoria; assim como facetas de uma mesma realidade são, por natureza, incindíveis, pois se combinam em um sistema binário de correlação e de interferência recíproca, imprimindo caráter especial aos direitos intelectuais. Os direitos respeitantes ao liame pessoal entre autor e obra são, assim, inseridos, pela doutrina, entre os direitos de personalidade." 36

A questão então se baseia o Direito Civil, Direito Comercial, Consumidor e Direito da Empresa são direitos generalizáveis ou não em relação á PESSOA, como base de todo raciocínio jurídico. Para sermos consumidores precisamos sim, sermos PESSOAS, mas apesar de consumirmos, o Direito do Consumidor não é Direito Civil, mesmo sendo praticado por PESSOAS. O direito do consumidor surge como "uma resposta ao fato inconteste de que a dinâmica do direito mercantil já se lastrava para relaçóes várias que

34 JABORANDY, Clara Cardoso Machado .op. cit. P. 68

35 ASCENSÃO, José de Oliveira, ibem idem. P.55

36 BITTAR, Carlos Alberto Bittar. Os direitos de personalidade, São Paulo: Saraiva, 2015, p.215. 
atingiam também os não comerciantes. Como os consumidores passaram a depender de crédito e de uma infindável quantidade de relaçóes de compra e venda ou prestação de serviços, a tutela específica relação jurídica se fez necessária." ${ }^{37}$

\section{Conclusões}

A pessoa não é o núcleo do Direito Civil, apesar de seus contornos jurídicos esteja no Direito Civil. É sabido que não existe área de Direito totalmente autônoma. A Pessoa que se tornará sujeitos de direitos aparecerá em vários ramos do Direito, nos microssistemas, ao criar vínculos, base das relaçóes jurídicas. "Consideraria a pessoa no trafego jurídico: quer ainda a pessoa em si, como que respeita a capacidade, quer a pessoa na dinâmica jurídica, como titular de situaçóes jurídicas, particularmente como parte em relaçóes jurídicas. Mas a Pessoa apareceria aqui no aspecto funcional e não essencial e com isto sujeita a parificaçóes com entidades que não são pessoas ontológicas. (...) Só desta maneira se tornará transparente a realidade da pessoa como o centro de gravidade do Direito e se alcançará uma base segura para extrair todas as consequências desta posição." ${ }^{38}$

Quanto ao Direito de Empresa, a figura da Pessoa também aparecerá na sua parte essencial quando as mesmas constituem suas sociedades e quando também existe a desconsideração da pessoa jurídica. Aparecerá a Pessoa no seu aspecto essencial e aparecerá também no seu aspecto funcional em vários microssistemas que tratarão de várias matérias do ramo de direito empresarial. Apesar do Direito de Empresa estar situado no Código Civil, reflexo da Unificação do Direito Privado baseada na teoria italiana, no entanto, a aprovação de novo Código Comercial urge. Ao lado das normas gerais do cidadão, como Pessoa, exaradas no Código Civil, teremos também a Pessoa no seu aspecto funcional em regras especiais como a proteção ao Consumidor, normas que tratam do empregado, normas tratando da empresa para dar maior segurança jurídica nas relaçóes econômicas do século XXI. É sabido que o Direito é subordinado aos ditames da economia, porque não falar em dirigismo contratual com base nas regras no direito da economia. $\mathrm{O}$ direito comum entre o Direito civil e o comercial seria o direito obrigacional e não a unificação completa do Comercial no Código civil; isto tampouco influi na autonomia do direito comercial. O fenômeno da comercialização do direito civil vem ratificar que a PESSOA aparece como sujeitos de direitos, ou seja, na convivência de vários ramos do direito (análise econômica do direito - AED) ${ }^{39}$. Ao interpretar a lei posta segundo os parâmetros da

37 WAISBERG, Ivo . O projeto de lei n.1572/2011 e a Autonomia do Direito Comercial in Reflexôes sobre o Projeto de Código Civil, São Paulo: Saraiva, 2013,p.70

38 ASCENSÃO, José de Oliveira, op. Cit. P.56.

39 "A Análise econômica do direito (AED) é um método de análise do Direito. Ela se vale de ferramentas da Ciência Econômica - fundamentalmente da Microeconomia - para explicar o Direito e resolver 
AED e também ao opinar a cerca de mecanismos de análises de futuras leis encontramos o liame doutrinário também entre a teoria dos direitos fundamentais de Alexy, e a tópica, ao admitir interferência de outras áreas no Direito, ao permitir o jurista ir além da normatividade técnica. Ratifica meu raciocínio que a norma jurídica é ela o marco inicial e final ao mesmo tempo, pois ela é posta em determinado tempo e finda em outro. Quando isso acontece, a norma jurídica finda renasce em outra norma jurídica inicial de outro tempo.

Em resumo, examinamos, no seu percurso histórico, as relações entre ética, justiça, Direito e a progressiva formulação e complexificação da noção de pessoa, fulcro da nossa meditação que teve como fio condutor, a repercussão dessa noção nas diferentes áreas do Direito contemporâneo. Nosso exame privilegiou o exame da contribuição de Paul Ricoeur para a complexificação e reformulação do conceito, bem como para considerarmos as repercussóes de suas teses no âmbito do Direito contemporâneo.

\section{Referências}

ALEXY, Robert. Teoria dos Direitos fundamentais. 2 ed., São Paulo: Malheiros, 2014. Constitucionalismo Discursivo, $5^{\mathrm{a}}$ ed., Porto Alegre: Livraria do Advogado, 2015 .

ASCENSÃO, José de Oliveira. O Direito Civil como o Direito Comum do Homem Comum in www.idb-fdul.com.

ÁVILA, Flávia de. Direito e Direitos Humanos. Curitiba: Editora Appris, 2014.

BELTRÃO, Ś́lvio Romero. Direitos da personalidade. 2 ed., São Paulo: Editora Atlas, 2014.

BITTAR, Carlos Alberto Bittar. Os direitos de personalidade, São Paulo: Saraiva, 2015.

BODENHEIMER, Edgard. Ciência do Direito: filosofia e metodologias científicas. Trad. Enéas Marzano. Rio de Janeiro: Forense.

CESAR, Constança Marcondes, El mismo y el outro: una perspectiva sobre la noción de persona em Paul Ricoeur, , Ágora. Papeles Filosóficos, vol.25, n.2, Universidade de Santiago de Compostela, 2008, p.197-206.

problemas jurídicos. Como em qualquer paradigma científico - como a Sociologia do Direito - existem várias escolas, várias vertentes. Não há um único método, nem a forma correta de se trabalhar com as lentes analíticas da economia aplicada ao Direito.(...) A AED positiva, então esforça-se em mostrar como as normas jurídicas evoluíram de modo a agregar eficiência á sociedade, diminuindo o custo das transaçóes e estimulando as relaçóes econômicas. Já a AED normativa emitirá opiniốes sobre a adequação ou não de determinadas regras jurídicas a fins últimos. ” TIMM, Luciano Benetti . Precisamos de um Novo Código Comercial? In Reflexôes sobre o projeto de Código Civil, São Paulo: Saraiva, 2013, p. $85 / 86$. 
. Direito, Justiça e Razáo, digitado, 2015.

COELHO, Fábio Ulhoa. O futuro do direito comercial. São Paulo: Editora Saraiva, 2011.

. Princípios do direito comercial. São Paulo: Editora Saraiva, 2012.

. Reflexóes sobre o Projeto de Código Comercial. São Paulo: Editora Saraiva,2013.

CANOTILHO, José J. Gomes Direito Constitucional e Teoria da Constituiçáo. 5 ed., Coimbra: Almedina, 2002.

FABRE-GOYARD, Simone. Os fundamentos da ordem jurídica. 2 ed., São Paulo: Martins Fontes, 2007.

HESSE, Konrad. A força normativa da Constituiçáo. Porto Alegre: Sergio Antônio Fabris Editor, 1991.

JABORANDY, Clara Cardoso Machado . A influência da hermenêutica constitucional para a formaçáo do raciocínio do intérprete in Hermenêutica Aplicada, São Paulo: Saraiva, 2014, p.59.

WAISBERG, Ivo . O projeto de lei n.1572/2011 e a Autonomia do Direito Comercial in Reflexôes sobre o Projeto de Código Civil, São Paulo: Saraiva, 2013, p.70.

MONTEIRO, Cláudia Servilha. Temas de Filosofia do Direito. Florianópolis: fundação Boiteux, 2004.

PAMPLONA FILHO, Rodolfo e Luis Carlos de Assis Jr, Hermenêutica aplicada, São Paulo: Saraiva, 2015.

PEREIRA, Ademar. in Contribuição da Dogmática Jurídica para a Ciência do Direito e suas Relaçóes. Revista Direito Mackenzie. N. 2 - Ano 1, p. 186.

RICOEUR, Paul. O justo. v. 1. São Paulo: WMF Martins Fontes, 2008.

. Éthique et politique in Du texte à l'action. Paris: Seuil, 1986. p. 393/406.

. Le juste entre le legal et le bon in Lectures 1. Paris: Seuil, 1991. p. 176/195.

ROMMEN, Henri. Le Droit Naturel - Histoire Doctrine. Paris: ECLOFF, 1945.

SCHREIBER, Anderson. Direitos da personalidade. 2 ed., São Paulo: Editora Atlas, 2013.

TIMM, Luciano Benetti . Precisamos de um Novo Código Comercial? In Reflexôes sobre o projeto de Código Civil, São Paulo: Saraiva, 2013, p.85/86.

TRISTÃO, Ivan e Zilmar Fachin. In Teoria Geral do Direito e suas Relaçóes com a Nova Hermenêutica e o (Neo) Constitucionalismo. Trabalho apresentado no XXII do CONPEDI em 2008. 